Parakomarekiella sesnandensis gen. et sp. nov. (Nostocales, Cyanobacteria) isolated from the Old Cathedral of Coimbra, Portugal (UNESCO World Heritage Site)

Fabiana Soares, Vítor Ramos , João Trovão, Susana M. Cardoso , Igor Tiago \& António Portugal

To cite this article: Fabiana Soares , Vítor Ramos , João Trovão, Susana M. Cardoso, Igor Tiago \& António Portugal (2020): Parakomarekiella sesnandensis gen. et sp. nov. (Nostocales, Cyanobacteria) isolated from the Old Cathedral of Coimbra, Portugal (UNESCO World Heritage Site), European Journal of Phycology, DOI: 10.1080/09670262.2020.1817568

To link to this article: https://doi.org/10.1080/09670262.2020.1817568

View supplementary material $\widetilde{ }$

Published online: 27 Oct 2020.

Submit your article to this journal $\llbracket$

Џll Article views: 111

Q View related articles $\llbracket$

View Crossmark data $₫$ 


\title{
Parakomarekiella sesnandensis gen. et sp. nov. (Nostocales, Cyanobacteria) isolated from the Old Cathedral of Coimbra, Portugal (UNESCO World Heritage Site)
}

\author{
Fabiana Soares ${ }^{\mathrm{a}}$, Vítor Ramos ${ }^{\mathrm{b}}$, João Trovão ${ }^{\mathrm{a}}$, Susana M. Cardoso ${ }^{\mathrm{c}}$, Igor Tiago ${ }^{\mathrm{a}}$ and António Portugal ${ }^{\mathrm{a}}$ \\ ${ }^{a}$ University of Coimbra, Centre for Functional Ecology, Department of Life Sciences, Calçada Martim de Freitas, 3000-456 \\ Coimbra, Portugal; ${ }^{b}$ Centro de Investigação de Montanha (CIMO), Instituto Politécnico de Bragança, Campus de Santa Apolónia, \\ 5300-253 Bragança, Portugal; ' LAQV-REQUIMTE, Chemistry Department, University of Aveiro, 3810-193 Aveiro, Portugal
}

\begin{abstract}
In a study that aimed to fingerprint the phototrophic community of the biodeteriorated walls of the Old Cathedral of Coimbra (UNESCO World Heritage Site), an unknown Nostoc/Komarekiella-like cyanobacterium was isolated. We employed a polyphasic approach based on morphological, ecological and phylogenetic analyses of the partial $16 \mathrm{~S}$ and the whole 16S-23S ITS rRNA regions to characterize this organism. Our strains shared 16S rRNA gene sequence similarity of 99-100\% with GenBank-assigned 'Nostoc sp.' sequences, and 98\% similarity with the genera Goleter, Roholtiella, Aulosira and Komarekiella. Despite being morphologically similar to Komarekiella, phylogenetic analyses placed our strains in a separated genus-level clade, distant from Nostoc sensu stricto and with Komarekiella as the closest taxon. Considering all molecular, phylogenetic and ecological data, we here propose Parakomarekiella sesnandensis F.Soares, V.Ramos \& A. Portugal, gen. et sp. nov.
\end{abstract}

ARTICLE HISTORY Received 26 May 2020; Revised 30 July 2020; Accepted 22 August 2020

KEYWORDS 16S rRNA; 16S-23S ITS; cyanobacteria; limestone; novel taxa; UNESCO

\section{Introduction}

Cyanobacteria are considered to be cosmopolitan microorganisms occurring in a wide variety of marine, freshwater and terrestrial habitats (Hoffmann, 1989; Albertano, 2012). Although the colonization of terrestrial habitats involves exposure to more severe conditions than in aquatic environments (Hoffmann, 1989), cyanobacteria are generally well adapted to such conditions due to their ability to develop morphological and physiological adaptations and other protection mechanisms. Such mechanisms involve, for example, the induction of a dormancy state and production of UV-protecting pigments, such as scytonemins and mycosporine-like amino acids (MAAs) (Hoffmann, 1989; Karsten et al., 2005; Hallmann, 2015). This set of unique characteristics combined with their phototrophic nature and ability to fix nitrogen allows them to colonize the surface and the interior of stone monuments (epilithic and endolithic colonization, respectively; Crispim \& Gaylarde, 2005; Macedo et al., 2009; Sterflinger \& Piñar, 2013). Besides the formation of coloured patinas as a result of their epilithic colonization, cyanobacteria are also able to exert pressure in the interior of the stone due to hydration-dehydration processes, leading to increased porosity and material loss (Saiz-Jimenez, 1999; Macedo et al., 2009). Additionally, they are also capable of intra- and extracellular calcium carbonate biomineralization (Benzerara et al., 2014), and stone dissolution through production of organic acids (Saiz-Jimenez, 1999; Macedo et al., 2009). All these processes lead to stone biodeterioration and loss of valuable cultural heritage materials. Therefore, the isolation and subsequent identification of novel taxa from cultural heritage monuments is an important step towards monument preservation and conservation, shedding light on the biodeterioration mechanisms of rock-inhabiting microorganisms. Recently, Soares et al. (2019a) characterized the phototrophic community inhabiting the limestone walls of the Old Cathedral of Coimbra, Portugal, using culture-dependent and -independent methodologies. Following this work, some novel taxa from this UNESCO monument have been isolated and described (see Soares et al., 2019b). Consequently, the aim of this study was to characterize the previously isolated Nostoc/Komarekiella-like strains based on ecological and morphological information, and phylogenetic analyses of the partial 16S rRNA and the whole 16S-23S ITS rRNA gene amplicons.

The cyanobacterial genus Nostoc has been reported as one of the most challenging groups in the order Nostocales (Řeháková et al., 2007; Hrouzek et al., 2013; Saraf et al., 2019). This genus has a complex life cycle (Lazaroff \& Vishniac, 1961; Lazaroff, 1966; Mollenhauer, 1970), a vast genetic and ecological diversity (Lyra et al., 2001; Meeks et al., 2001; Henson et al., 2002; Iteman et al., 2002; Hrouzek et 
al., 2005; Rajaniemi et al., 2005; Řeháková et al., 2007; Suradkar et al., 2017) and cryptic morphology among

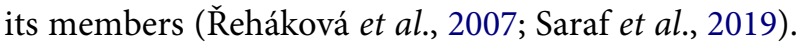
In addition, Nostoc is considered polyphyletic (Hrouzek et al., 2005; Řeháková et al., 2007; Papaefthimiou et al., 2008). As a result, several novel genera morphologically similar to Nostoc, but phylogenetically separated from the Nostoc sensu stricto clade, are now being established (e.g. Mojavia Reháková \& Johansen (Reháková et al., 2007); Desmonostoc (C.Agardh ex Bornet \& Flahault) Hrouzek \& Ventura (Hrouzek et al., 2013); Halotia D.B.Genuário et al. (Genuário et al., 2015); Komarekiella Hentschke, J.R.Johansen \& Sant'Anna (Hentschke et al., 2017); Aliinostoc Bagchi, Dubey \& P.Singh (Bagchi et al., 2017)).

Although morphologically similar to the genus Komarekiella, our strains resolved within a supported clade distant from Nostoc sensu stricto, but closer to a clade that encompassed GenBank-defined 'Nostoc sp.' sequences obtained by Cuzman et al. (2010), with the genus Komarekiella as the closest taxon. We propose the erection of a new cyanobacterial genus Parakomarekiella gen. nov. and Parakomarekiella sesnandensis sp. nov. to accommodate our strains.

\section{Materials and methods}

\section{Site description and sampling}

The Old Cathedral of Coimbra (Coimbra, Portugal, $40^{\circ} 12^{\prime} 32^{\prime \prime} \mathrm{N}, 8^{\circ} 25^{\prime} 38^{\prime \prime} \mathrm{W}$ ) is an emblematic Portuguese Romanesque Church. The cathedral was constructed during the 12th and the 13th centuries and consists of a single cloister floor surrounded by five lateral chapels. This cathedral has remained almost intact since Reconquista times and, for this reason, all chapels are now showing severe signs of biodeterioration (green/ dark-green biofilms and salt formation). All chapels were carved from yellow dolomitic limestone, a carbonate rock mainly composed of calcium magnesium carbonate. Its chemical composition includes 23-31\% $\mathrm{CaO}, 16-21 \% \mathrm{MgO}, 0.8-4 \% \mathrm{Fe}_{2} \mathrm{O}_{3}$ and residual quantities of other oxides (Manupella et al., 1981; Quinta-Ferreira et al., 1992; Catarino et al., 2019).

During a study aiming to fully characterize the phototrophic community inhabiting the limestone walls of the Old Cathedral of Coimbra (see Soares et al., 2019a) two Nostoc/Komarekiella-like strains were collected. These strains were obtained from two different biofilms scrapped off from the limestone walls of one of the chapels composing the Cathedral (Chapel of São Nicolau). The cyanobacterial strains were isolated from liquid enrichment cultures by means of micromanipulation using an inverted microscope and inoculated into flask tubes containing liquid $\mathrm{BG}_{11}$ and $\mathrm{BG}_{11}(-\mathrm{N})$ culture media (Rippka et al., 1979). Inoculates were then incubated at $20 \pm$ $1^{\circ} \mathrm{C}$, under a 16: $8 \mathrm{~h}$ (light: dark) photoperiod (30-40 $\mu \mathrm{mol}$ photons $\mathrm{m}^{-2} \mathrm{~s}^{-1}$ irradiance) until there was enough biomass for DNA extraction.

\section{Morphological analysis}

Strain morphology was studied using both light microscopy and a transmission electron microscope (TEM). Photomicrographs were captured with a Leica microscope Model DM4000B (Leica, Germany) coupled to a camera. Morphological analysis was performed by evaluating the strains' life cycle, size of vegetative cells, heterocysts and akinetes, under culture conditions. In addition, we also compared our strains with Komarekiella atlantica.

For TEM analysis, samples were fixed with $2.5 \%$ glutaraldehyde in $0.1 \mathrm{M}$ sodium cacodylate buffer $(\mathrm{pH}$ 7.2) for $2.5 \mathrm{~h}$ and post-fixed using $2 \%$ osmium tetroxide for $2 \mathrm{~h}$. Cells were then dehydrated in a graded ethanol series (70-100\%), embedded in $2 \%$ molten agar, re-dehydrated in ethanol (70-100\%), impregnated and embedded using an Epoxy Embedding Kit (Fluka ${ }^{\circledR}$ Analytical, USA). Ultrathin sections (70 $\mathrm{nm}$ ) were obtained with an ultramicrotome (Leica EM UC6), mounted on copper grids and observations were carried out on a FEI-Tecnai G2 Spirit Bio Twin at $100 \mathrm{kV}$.

\section{DNA extraction, PCR amplification and sequencing}

Genomic DNA was extracted using the NZY Microbial gDNA Isolation kit (NZYTech ${ }^{\mathrm{m}}$, Portugal), following the manufacturer's protocol. DNA extractions were visualized on a $1.5 \%$ agarose gel and quantified with a NanoDrop $^{\text {ma }}$ 2000c spectrophotometer (Thermofisher Scientific $^{\mathrm{mm}}$, USA). Genomic DNA of each isolate was subjected to amplification of partial 16S rRNA (with primer pairs Cya106F/Cya781R and Cya359/ Cya1494R) (Neilan et al., 1997; Nübel et al., 1997), and the whole 16S-23S ITS rRNA (with primer pair $\mathrm{P} 2 / \mathrm{P} 1$; Boyer et al., 2001) gene fragments. Amplification of the 16S rRNA gene fragment was performed according to Cunha de Oliveira et al. (2019), with $12.5 \mu \mathrm{l}$ of NZYTaqGreen Master MIX (NZYTech ${ }^{\mathrm{Tx}}$, Portugal), $1 \mu \mathrm{l}$ of each primer $(10 \mathrm{mM})$, $9.5 \mu \mathrm{l}$ ultra-pure water and $1 \mu \mathrm{l}$ template DNA, in a final reaction volume of $25 \mu \mathrm{l}$. PCR reactions were performed using an ABI GeneAmp ${ }^{\text {TM }} 9700$ PCR System (Applied Biosystems, USA), with conditions as follows: initial 2 min denaturation step at $95^{\circ} \mathrm{C}$, followed by 35 cycles of denaturation at $95^{\circ} \mathrm{C}$ for $1 \mathrm{~min}$, annealing at $55^{\circ} \mathrm{C}$ for $45 \mathrm{~s}$, extension at $72^{\circ} \mathrm{C}$ for $1 \mathrm{~min}$, and a final extension at $72^{\circ} \mathrm{C}$ for $10 \mathrm{~min}$. PCR products were visualized by electrophoresis on a $1 \%$ agarose gel, purified and sequenced with the same primers described above using an ABI 3730 genetic analyser, using the Big 
Dye v.3.1 Terminator Cycle Sequencing Ready Reaction Kit (Applied Biosystems, USA; STABVIDA, Portugal).

Amplification of the 16S-23S ITS rRNA gene region was performed according to Boyer et al. (2001), with $15 \mu \mathrm{l}$ of NZYTaqGreen Master MIX (NZYTech $^{\mathrm{Tm}}$, Portugal), $1 \mu \mathrm{l}$ of each primer (10 $\mathrm{mM}), 12 \mu \mathrm{l}$ of ultra-pure water and $1 \mu$ lof template DNA, in a final reaction volume of $30 \mu \mathrm{l}$. PCR amplification was performed using an ABI GeneAmp ${ }^{\mathrm{TM}}$ 9700 PCR System (Applied Biosystems, USA), with the following conditions: initial denaturation at $94^{\circ} \mathrm{C}$ for $1 \mathrm{~min}$, followed by 35 cycles of denaturation at $94^{\circ} \mathrm{C}$ for $1 \mathrm{~min}$, annealing at $57^{\circ} \mathrm{C}$ for $1 \mathrm{~min}$, extension at $72^{\circ} \mathrm{C}$ for $4 \mathrm{~min}$, and a final extension at $72^{\circ} \mathrm{C}$ for $10 \mathrm{~min}$. PCR products were visualized by electrophoresis on a $1 \%$ agarose gel, purified and sequenced with primers $\mathrm{P} 2$ and $\mathrm{P} 1$, and an additional internal primer P5 (Boyer et al., 2001).

\section{$16 S$ rRNA phylogenetic analyses}

The obtained sequences were trimmed and assembled using Geneious ${ }^{\circledR}$ 10.2.2 software (https://www.gen eious.com). Sequences were deposited in GenBank (with accession numbers MT044190-MT044192) and compared with available sequences in the National Center for Biotechnology Information (NCBI) by BLASTN (Altschul et al., 1990).

For Bayesian inference (BI) and Maximum likelihood (ML) 16S rRNA phylogenetic analyses, two distinct sequence datasets were constructed. Both datasets consisted of sequences obtained in this study and additional sequences of reference strains from the Nostocales, based on Hentschke et al. (2017). However, since our strains showed 99-100\% identity with GenBank-assigned 'Nostoc sp.' sequences obtained by Cuzman et al. (2010), those were also included in the first dataset. The second dataset excluded the 'Nostoc sp.' sequences obtained by Cuzman et al. (2010). The first final 16S rRNA dataset included 82 sequences for a total of 1256 aligned positions, and the second included 77 sequences for a total of 1258 aligned positions. Both datasets were aligned using MAFFT v.7.0 (Katoh \& Standley, 2013), and the resulting alignments (Supplementary data S1 and S2) were manually checked and corrected (when applicable) using UGENE 1.26.3 (Okonechnikov et al., 2012), and were used to construct the phylogenetic trees. GTR+I+G was the bestfit model for all BI and ML analyses, estimated using MrModeltest v.2.4 (Nylander, 2004) based on the Akaike Information Criterion (AIC). Bayesian Markov Chain Monte Carlo (MCMC) analyses were performed using MrBayes v.3.2.6 (Ronquist et al., 2012), and four runs over an initial number of 10 million generations were conducted. The standard value for heat chain temperature was 0.15 and trees were set to be saved after every 100 generations. The run was set to stop when the average standard deviation of split frequencies fell below 0.01. Tracer v.1.5 software (Rambaut \& Drummond, 2007) was used after Bayesian analysis to ensure that the stationary phase and convergence of the tree had been reached. For the first dataset, the MCMC analysis ran for 2120 000 generations resulting in 63514 sampled trees. For the second, the MCMC analysis ran for 2170000 generations resulting in 65090 sampled trees. In both analyses, $25 \%$ of the trees were discarded as part of the burn-in phase.

For the ML phylogenetic analyses, trees were constructed using the IQTree online version (Trifinopoulos et al., 2016) with selected option "approximate Bayes test" and 1000 bootstrap replicates (see Supplementary data S3). For all phylogenetic analyses, Gloeobacter violaceus PCC 8105 was set to root the tree, and FigTree v.1.2.2 (Rambaut \& Drummond, 2008) was used for tree visualization (see Supplementary data S3-S6).

\section{ITS secondary structure}

The secondary structures D1-D1', Box-B, V2 and V3 of the ITS regions were found using LocARNAAlignment and Folding (Will et al., 2007, 2012; Smith et al., 2010), and were folded individually using the Mfold WebServer 3.5 with default conditions, except for the application of the structure draw mode with 'untangle loop fix' (Zuker, 2003). The tRNA genes were found using the tRNAscan-SE 2.0 webserver (Lowe \& Chan, 2016).

\section{Results}

\section{S rRNA phylogenetic analyses and secondary structure of 16S-23S ITS}

The 16S rRNA sequences of our two isolates were identical and when compared with their closest relatives showed high similarity with GenBank-assigned 'Nostoc sp.' sequences obtained by Cuzman et al. (2010) in a study characterizing the diversity of phototrophic organisms in monumental fountains. Specifically, our strains were identical to 'Nostoc sp. $5 \mathrm{~N}-02 \mathrm{c}$ ', 99.7\% similar to 'Nostoc sp. 2-07' and 'Nostoc sp. VP2-08', and 99.3\% similar to 'Nostoc sp. 9E-03'. These strains fall within the Parakomarekiella clade, which is distant from Nostoc sensu stricto sequences (dataset 1; Fig. 1). Since the resulting BI and ML phylogenetic trees showed the same topology, a single tree with both Bayesian posterior probabilities (PP) and ML bootstrap values is shown. Results from these phylogenetic analyses (Fig. 1) showed that our strains formed a well-supported (0.97 PP; 85\% bootstrap) and separated cluster encompassing the GenBank-assigned 'Nostoc sp.' sequences, with the 


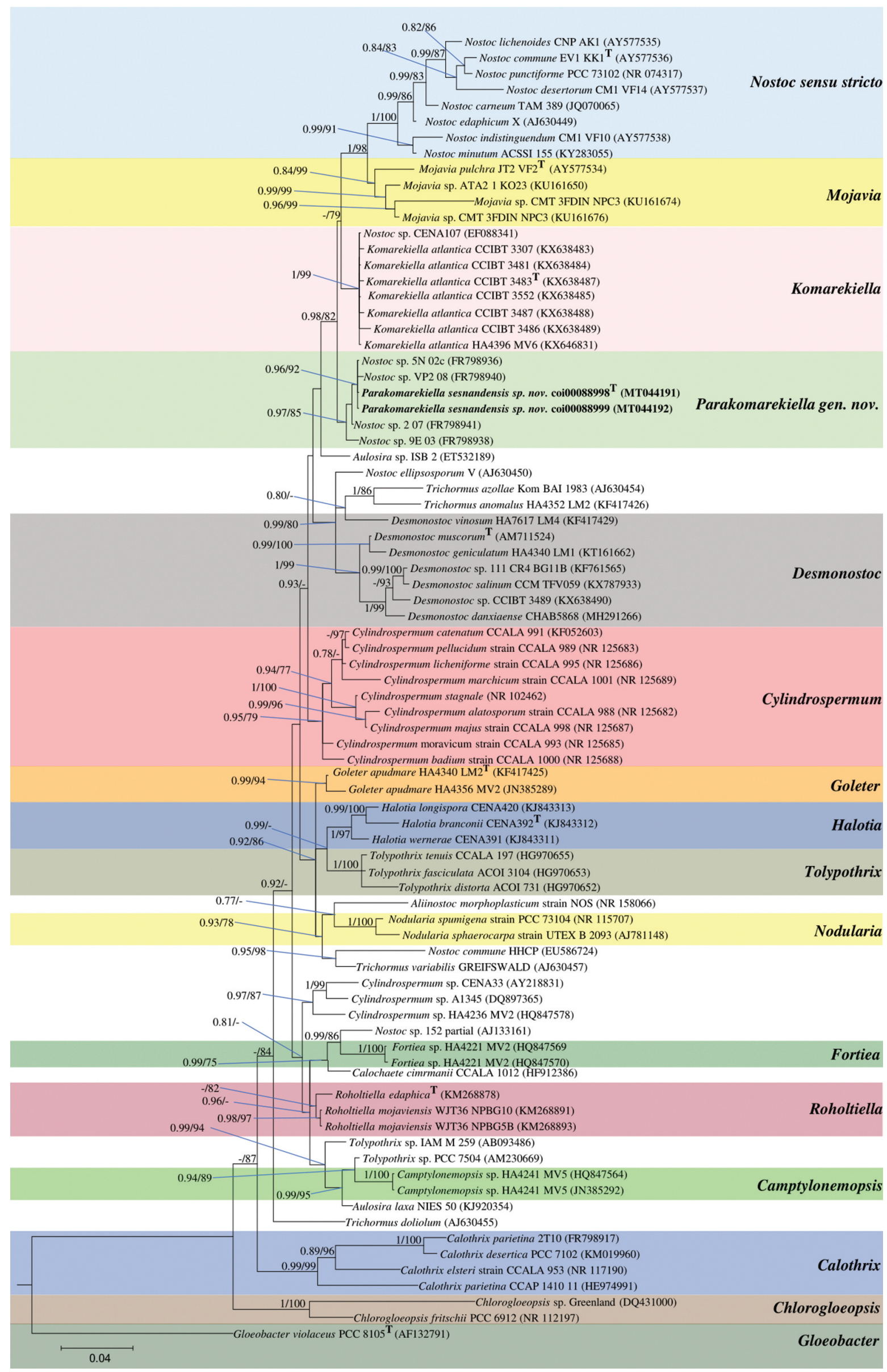

Fig. 1. Phylogenetic tree based on Bayesian and Maximum likelihood analyses from partial 16S rRNA gene sequences (dataset 1). Since the resulting Bayesian and ML phylogenetic trees showed the same topology, a single tree with both Bayesian and ML bootstrap values is shown. Supports at the nodes (Bayesian inference/Maximum likelihood) represent posterior probabilities and bootstrap values $\geq 75$. The studied strains are shown in bold, and Gloeobacter violaceus PCC 8501 was used to root the tree. The scale bar specifies 0.04 expected changes per site. ' $T$ ' indicates a Type/reference strain (i.e. an isolate used todescribe the genus or an isolate known to have the same phylogenetic placement as the Type species, after taxonomic revision). 
genus Komarekiella as the closest relative. The phylogenetic analyses of dataset 2 showed a fully supported (1/100; PP and bootstrap, respectively) genus-level separation for the studied strains; only one tree is shown (Supplementary fig. S1).

The 16S rRNA $p$-distance matrix showed similarity values $>95 \%$ between our strains and Type strains from related Nostocaceae genera (see Table 1). Our strains shared 99-100\% 16S rRNA similarity with 'Nostoc sp.' sequences; $98 \%$ with strains assigned to Goleter apudmare Miscoe \& J.R.Johansen (Miscoe et al., 2016), Roholtiella edaphica Bohunická \& Lukesová (Bohunická et al., 2015), Aulosira laxa O.Kirchner ex Bornet \& Flahault (Bornet \& Flahault, 1886) and all K. atlantica strains; 97\% with Mojavia pulchra, Desmonostoc muscorum and Cylindrospermum majus Kützing ex Bornet \& Flahault (Bornet \& Flahault, 1886), and 96\% sequence similarity with Trichormus variabilis (Kützing ex Bornet \& Flahault) Komárek \& Anagnostidis (Komárek \& Anagnostidis, 1989), Nostoc commune Vaucher ex Bornet \& Flahault (Bornet \& Flahault, 1888), Halotia branconii and Nodularia spumigea Mertens ex Bornet \& Flahault (Bornet \& Flahault, 1888).

The ITS region of Parakomarekiella sesnandensis possessed both tRNA ${ }^{\text {Ile }}$ and tRNA ${ }^{\text {Ala }}$ genes and the secondary structures D1-D1', Box-B, V2 and V3 (Figs 2-7, 8-13, 14-17 and 18-23, respectively). The ITS secondary structures of our two strains were $100 \%$ identical and were compared with the secondary structures of Komarekiella atlantica CCIBt 3483 (KX638487) and other nostocacean genera, namely Desmonostoc geniculatum HA4340-LM1 (KU161662), Halotia branconii CENA 392 (KJ843312), Mojavia pulchra JT2-VF2 (AY577534) and Nostoc commune EV1-KK1 (AY577536) (see Figs 2-23 and Table 2). In summary, all studied strains had very similar D1-D1' helix structure, with an equal helix shape and number of nucleotides varying from $64 \mathrm{nt}$ (M. pulchra) to $68 \mathrm{nt}$ (N. commune) (Figs 2-7; Table 2). The main differences were the existence of one unpaired nucleotide opposing the basal unilateral bulge on the 5' side of the helices of Parakomarekiella, D. geniculatum and $N$. commune instead of two, as shown in H. branconii and $M$. pulchra. As to $P$. sesnandensis and $K$. atlantica, differences resided mostly in the basal stem, in the existence of one unpaired nucleotide on the 5' side of the helices of Parakomarekiella instead of three and in some nucleotide substitutions (see Figs 2-7; Table 2). The Box-B helix of all studied strains was very similar in terms of length and shape, with the exception of D. geniculatum and $H$. branconii, which possessed longer helix lengths and different shapes (Figs 8-13; Table 2). All strains had the same basal stem, and the length of the helices varied from $26 \mathrm{nt}$ (K. atlantica and M. pulchra) to 48 nt (D. geniculatum). The V2 and V3 helices were highly variable among all taxa, with no consistent patterns observed (Figs 14-17 and 18-23, respectively). We were not able to find the V2 helices of Mojavia pulchra and Nostoc commune and, for that reason, these are not shown in Figs 14-17. The length of the V2 helices varied from $41 \mathrm{nt}$ in $P$. sesnandensis to $76 \mathrm{nt}$ in $H$. branconii (Table 2). The length of the V3 helices varied from $39 \mathrm{nt}$ in $N$. commune to $103 \mathrm{nt}$ in M. pulchra, $78 \mathrm{nt}$ in $P$. sesnandensis (Figs 18-23; Table 2).

\section{Taxonomic analysis}

\section{Parakomarekiella F.Soares, V.Ramos \& A.Portugal,} gen. nov. (Figs 24-40)

DIAGNOSIS: Morphologically similar to Komarekiella, from which it differs by the presence of an inclusion/ vesicle in the akinetes and smaller size of heterocytes. It also differs in sequences and in most of the ITS secondary structures of the conserved domains of the 16S-23S ITS region.

Description In nature, thalli microscopic, growing on limestone surfaces. In liquid media, forming thin biofilm layers attached to the walls of the test tube, or forming agglomerated dense aggregates deposited at the bottom of the test tube. Cells blue-green, dark green when mature. Cells spherical to subspherical, forming macroscopic compact dense aggregates, enclosed by a mucilage layer (Figs 24-26, 37-40). Cells in trichomes or sometimes free-living, isodiametric, quadrate, straight or straight to bent (Figs 33, 34). Cells divide in more than one plane, forming multiseriate trichomes (Fig. 26). Heterocytes intercalary and terminal (Figs 32, 33), placed laterally when cells are in compact aggregates. Akinetes spherical to subspherical, developing from vegetative cells in trichomes (Fig. 35), reproducing by equal division forming elongated trichomes surrounded by a thick, firm mucilage layer (Figs 27, 28, 35), or by unequal division forming bigger spherical and encapsulated colonies (Figs 29-31, 36). Akinetes with granular content and with frequent presence of inclusions/vesicles (Figs 29, 30, 34-36, 39). The thylakoid arrangement exhibits a fascicular architecture (Figs 38, 39).

TYPE SPECIES: Parakomarekiella sesnandensis ETYMOLOGY: The genus name was derived from the Greek pará = near, beside.

Parakomarekiella sesnandensis F.Soares, V.Ramos \& A.Portugal, sp. nov. (Figs 24-40)

Description Thallus microscopic, blue-green, later dark green, becoming yellowish when very old (more than 6 months). Cells at first forming thin biofilm layers attached to the walls of the test tubes, later forming 


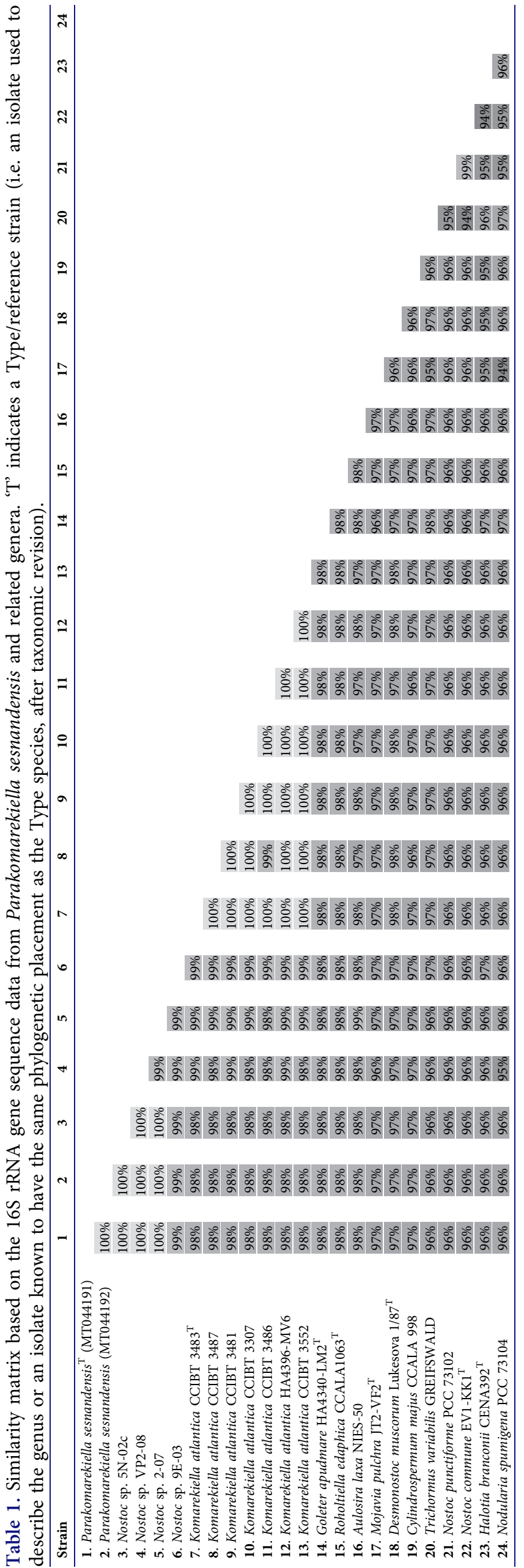

compact dense aggregates at the bottom of the test tube. Cells in hormogonia isodiametric, quadrate, sometimes wider than longer (1.8-3.4 $\mu \mathrm{m}$ long, 2.4$4.0 \mu \mathrm{m}$ wide); hormogonia straight or straight to bent, forming uniseriate filaments up to $4 \mu \mathrm{m}$ wide. Cells spherical or subspherical when mature, dividing in more than one plane, forming multiseriate filaments up to $15 \mu \mathrm{m}$ wide, creating compact and aggregated colonies. Akinetes spherical or subspherical (3.7-7.9 $\mu \mathrm{m}$ long, 3.2-6.1 $\mu \mathrm{m}$ wide), slightly larger than vegetative cells (2.8-6.3 $\mu \mathrm{m}$ long, 2.5-5.2 $\mu \mathrm{m}$ wide), with granular content and with frequent presence of a vesicle (1.2-2.6 $\mu \mathrm{m}$ in diameter). Heterocytes spherical when terminal; spherical, subspherical or compressed when intercalary $(2.1-3.7 \mu \mathrm{m}$ in diameter).

HOLOTYPE: (here designated): coi00088998, deposited at the Herbarium of the University of Coimbra, Portugal. Algal cultured material preserved in $4 \%$ formaldehyde.

ISOTYPE: coi00088999, deposited at the Herbarium of the University of Coimbra, Portugal. Algal cultured material preserved in $4 \%$ formaldehyde.

TYPE LOCALITY: Old Cathedral of Coimbra, Almedina, Coimbra $\left(40^{\circ} 12^{\prime} 32^{\prime \prime} \mathrm{N}, 8^{\circ} 25^{\prime} 38^{\prime \prime} \mathrm{W}\right)$, attached to the limestone walls of one of the chapels of the Cathedral. Sample collected 22 November 2016.

ETYMOLOGY: The species was named after D. Sesnando, the first governor of Coimbra, whose tomb is placed in the chapel where the samples were collected.

DNA SEQUENCES: Sequences were deposited in GenBank with accession numbers MT044190MT044192.

\section{Ecology}

The chapel from where the Parakomarekiella strains were isolated is in the southern area of the Old Cathedral of Coimbra. Due to its architecture, the chapel is not exposed to direct sunlight. During the sampling day, temperature was $\sim 11-12^{\circ} \mathrm{C}$ and the relative humidity inside the chapel was $64 \%$. In the year of sampling (2016), the average regional annual temperature was $16^{\circ}$ $\mathrm{C}$ and the average regional annual precipitation was 99 $\mathrm{mm}$ (data retrieved from The Portuguese Institute for Sea and Atmosphere; Supplementary table S1).

The strains were collected from two distinct biofilms - one was characterized as a dried green biofilm and the other was characterized as a mixture of wet and dried green biofilm with salt efflorescence (mainly gypsum) (Soares et al., 2019a). In both biofilms, the presence of other phototrophic and heterotrophic organisms (fungi) was noted. Phototrophic organisms were identified as Acutodesmus bajacalifornicus, Bracteacoccus sp., Pseudostichococcus 


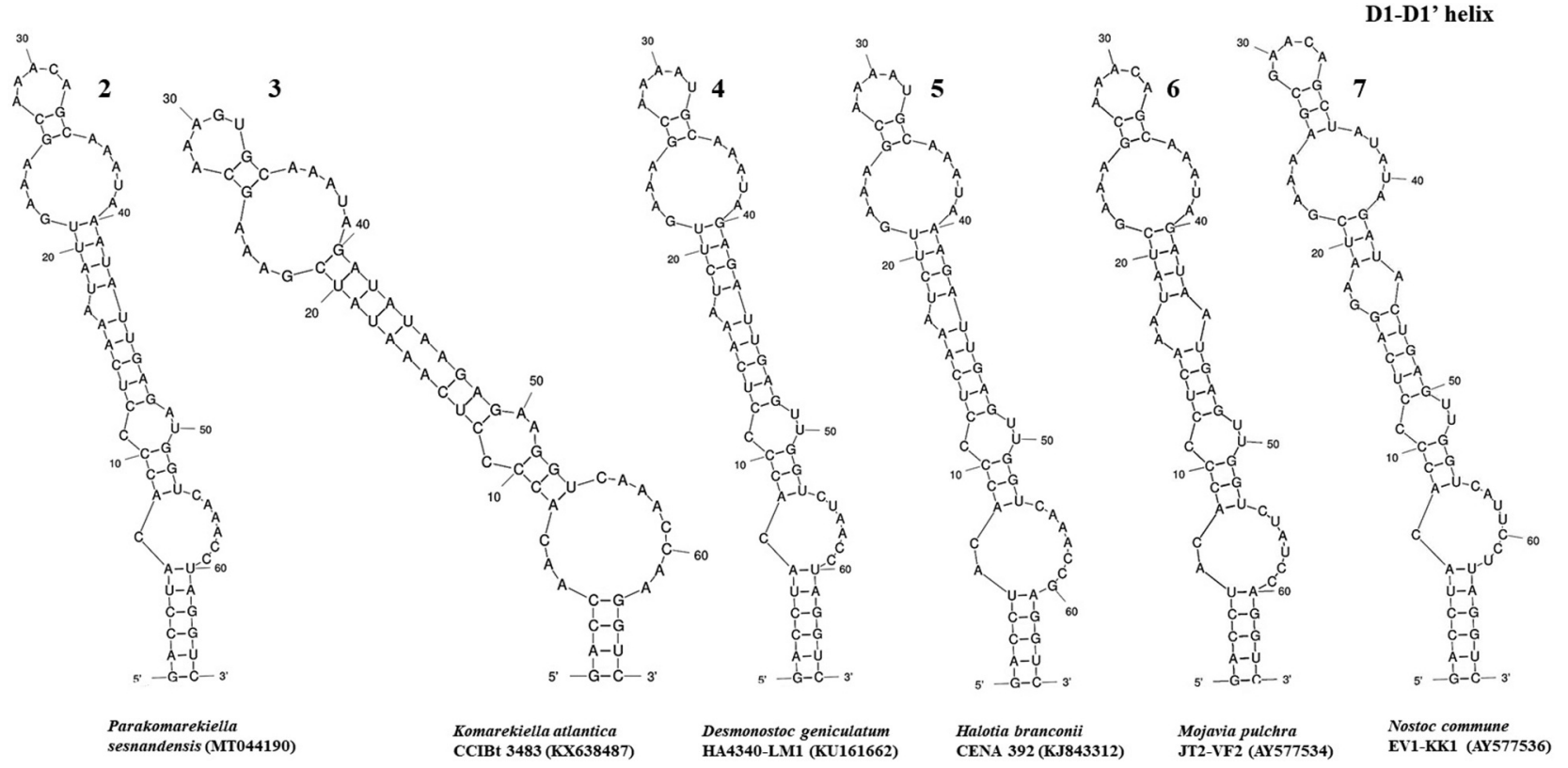

Figs 2-7. D1-D1' helix of the secondary structure of 16S-23S ITS region. Fig. 2. Parakomarekiella sesnandensis (MT044190); Fig. 3. Komarekiella atlantica CCIBt 3483 (KX638487); Fig. 4. Desmonostoc geniculatum HA4340-LM1 (KU161662); Fig. 5. Halotia branconii CENA 392 (KJ843312); Fig. 6. Mojavia pulchra JT2-VF2 (AY577534); Fig. 7. Nostoc commune EV1-KK1 (AY577536).

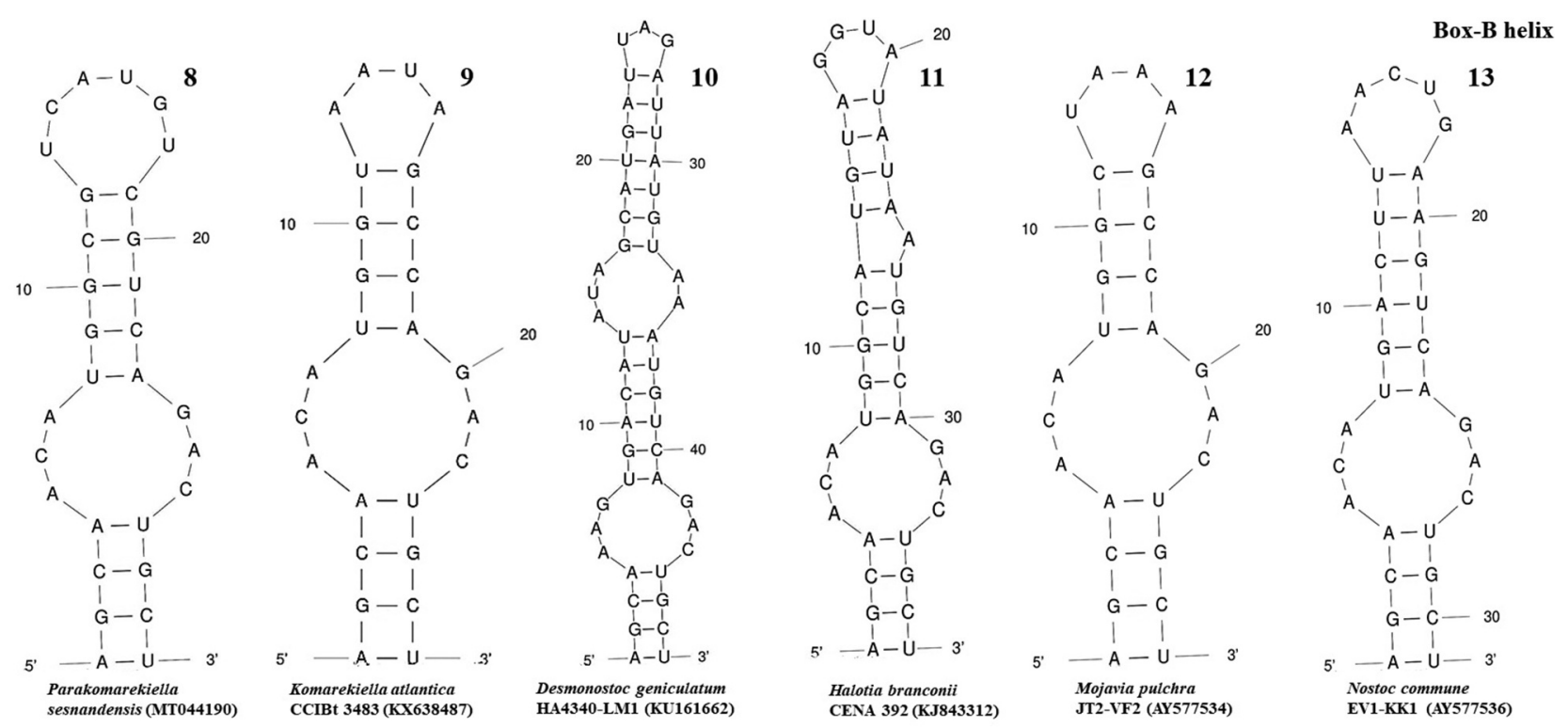

Figs 8-13. Box-B helix of the secondary structure of 16S-23S ITS region. Fig. 8. Parakomarekiella sesnandensis (MT044190); Fig. 9. Komarekiella atlantica CCIBt 3483 (KX638487); Fig. 10. Desmonostoc geniculatum HA4340-LM1 (KU161662); Fig. 11. Halotia branconii CENA 392 (KJ843312); Fig. 12. Mojavia pulchra JT2-VF2 (AY577534); Fig. 13. Nostoc commune EV1-KK1 (AY577536).

monallantoides, Heterochlamydomonas inaequalis and Nostoc punctiforme (see Soares et al., 2019a for details). Fungi in the genera Aspergillus, Cladosporium, Penicillium and Stagonosporopsis were dominant at these sites (Trovão et al., 2019a).

\section{Discussion}

Cultural heritage monuments are known to positively affect the tourism and economy of a country (Urzí \& De Leo, 2001). However, their inherent value can be lost due to weather conditions, pollution and deterioration by microorganisms (Scheerer et al., 2009). The ability of cyanobacteria to colonize such harsh environments leads to aesthetic and physicochemical alterations to stone monuments, challenging restorers and conservators worldwide. Stone substrata can be the source of new taxa (e.g. Villanueva et al., 2018, 2019; Soares et al., 2019b; Trovão et al., 2019b) with an unknown role as stone biodeteriogens. Therefore, studies employing culture-dependent approaches 


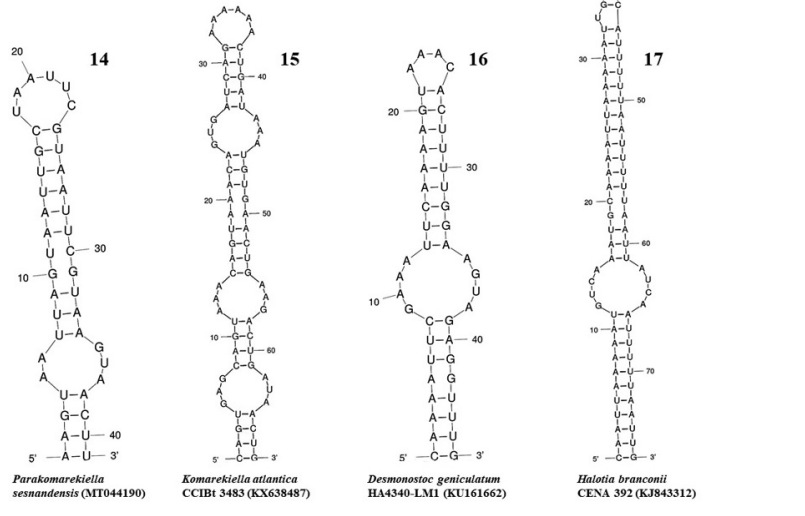

Figs 14-17. V2 helix of the secondary structure of 16S-23S ITS region. Fig. 14. Parakomarekiella sesnandensis (MT044190); Fig. 15. Komarekiella atlantica CCIBt 3483 (KX638487); Fig. 16. Desmonostoc geniculatum HA4340LM1 (KU161662); Fig. 17. Halotia branconii CENA 392 (KJ843312).

are recommended as they allow characterization of novel taxa and to understand their contribution to stone biodeterioration.

In the present study, a polyphasic approach based on phylogeny, morphology and ecology was performed to correctly classify and describe the proposed new genus Parakomarekiella and novel species $P$. sesnandensis. Morphologically, Parakomarekiella is very similar to Komarekiella, only differing by the presence of inclusions within the akinetes and in the smaller size of the heterocytes. These inclusions were observed both in $\mathrm{BG}_{11}$ and in $\mathrm{BG}_{11}(-\mathrm{N})$ culture media, in young and old cultures, and are likely to be cyanophycin granules, as reported for other nostocalean cyanobacteria such as Cylindrospermopsis raciborskii (Woloszynska) Seenayya \& Subba Raju (Seenayya \& Subba Raju, 1972; Moore et al., 2004), Chrysosporum ovalisporum (formerly Aphanizomenon ovalisporum) (Forti) E.Zapomelová, O. Skácelová, P.Pumann, R.Kopp \& E.Janecek (Zapomelová et al., 2012; Sukenik et al., 2015), Anabaena variabilis Kützing ex Bornet \& Flahault (Bornet \& Flahault, 1886) and Nostoc punctiforme Hariot (Hariot, 1891) (Perez et al., 2016). Additionally, thylakoid arrangement in Parakomarekiella exhibits a fascicular architecture, which prevails in the rarely branching and akinete-forming members of the Nostocaceae (Mares et al., 2019).

Komarekiella is morphologically similar to Mojavia, Desmonostoc, Halotia, N. punctiforme var. populorum, and is indistinguishable from Chlorogloeopsis, as observed and well summarized by Hentschke et al. (2017). So it follows that Parakomarekiella is also similar to these genera. However, it is known that some morphological traits are triggered by culture conditions, diverging from those observed in natural environments (Casamatta \& Vis, 2004; Perkerson et al., 2011). For that reason, and since Komarekiella, Mojavia and Chlorogloeopsis are still known only from cultured algae (Hentschke et al., 2017), their diagnostic features become even more challenging to differentiate. Consequently, in such cases, other analyses, namely phylogeny of the $16 \mathrm{~S}$ rRNA, $p$-distance and ITS secondary structure are important criteria to
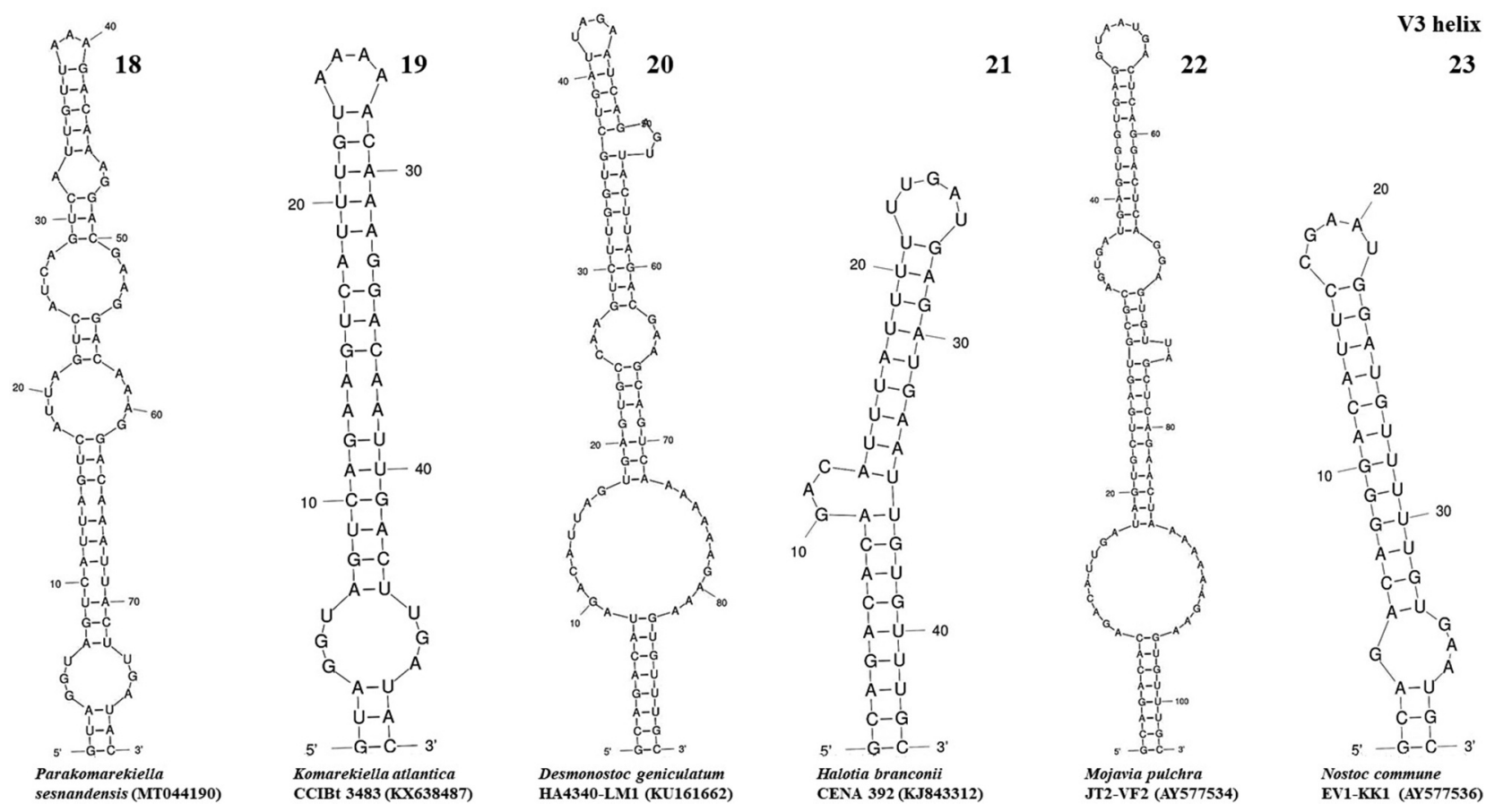

Figs 18-23. V3 helix of the secondary structure of 16S-23S ITS region. Fig. 18. Parakomarekiella sesnandensis (MT044190); Fig. 19. Komarekiella atlantica CCIBt 3483 (KX638487); Fig. 20. Desmonostoc geniculatum HA4340-LM1 (KU161662); Fig. 21. Halotia branconii CENA 392 (KJ843312); Fig. 22. Mojavia pulchra JT2-VF2 (AY577534); Fig. 23. Nostoc commune EV1-KK1 (AY577536). 
Table 2. Detailed description of the ITS secondary structures of Parakomarekiella sesnandensis and related genera.

\begin{tabular}{cc}
\hline & Strain \\
\hline Parakomarekiella & 6-residue basal stem (GACCUA-UAGGUC) + 7-residue asymmetrical internal loop (C-CAAACC) \\
sesnandensis (MT044191) & + 3-residue stem region (ACC-GGU) + 3-residue asymmetrical internal loop (C-AU) + 5-residue \\
(65 residues) & stem region (CUCAA-UUGAG) + single base left bulge (A) + 4-residue stem region (UAUU- \\
& AAUA) + 9-residue asymmetrical internal loop (GAAA-AAAUA) + 2-residue stem region (GC-
\end{tabular}

D1-D1' Komarekiella atlantica CCIBT 4-residue basal stem (GACC-GGUC) + 11-residue asymmetrical internal loop (AAC-CAAACCAA)

helix

3483
66 residues)

\section{Desmonostoc geniculatum HA4340-LM1}

(65 residues)

Halotia branconii CENA392 (65 residues)

Mojavia pulchra JT2-VF2 (64 residues)

Nostoc commune EV1-KK1 (68 residues)

\author{
Parakomarekiella \\ sesnandensis (MT044191) \\ (30 residues)
}

Box-B Komarekiella atlantica CCIBT 3483 (26 residues)

Desmonostoc geniculatum HA4340-LM1 (48 residues)

Halotia branconii CENA392 (37 residues)

Mojavia pulchra JT2-VF2 (26 residues)

Nostoc commune EV1-KK1 (31 residues)

Parakomarekiella sesnandensis (MT044191)

(41 residues)

V2 helix Komarekiella atlantica CCIBT 3483

(68 residues)

Desmonostoc geniculatum

HA4340-LM1

(46 residues)

Halotia branconii CENA392

(76 residues)

Parakomarekiella sesnandensis (MT044191)

(78 residues)

V3 helix Komarekiella atlantica CCIBT 3483 (50 residues)

Desmonostoc geniculatum HA4340-LM1 (90 residues)

Halotia branconii CENA392 (44 residues)
+ 3-residue stem region (ACC-GGU) + 3-residue asymmetrical internal loop (C-AA) + 10 residue stem region (CUCAAAUAUC-GAUAUAAGAG) + 9-residue asymmetrical internal loop (GAAA-AAAUA) + 2-residue stem region $(\mathrm{GC}-\mathrm{GC})+5$-residue terminal hairpin (AAAGU)

6-residue basal stem (GACCUA-UAGGUC) + 7-residue asymmetrical internal loop (C-CUAACC) + 3-residue stem region (ACC-GGU) + 3-residue asymmetrical internal loop (C-UU) + 5-residue stem region (CUCAA-UUGAG) + single base left bulge (A) + 4-residue stem region (UCUUGAGA) + 9-residue asymmetrical internal loop (GAAA-AAAUA) + 2-residue stem region (GC$\mathrm{GC})+5$-residue terminal hairpin (AAAAU)

5-residue basal stem (GACCU-AGGUC) + 9-residue asymmetrical internal loop (AC-CAAACCG) + 3-residue stem region (ACC-GGU) + 3-residue asymmetrical internal loop (C-UU) + 5-residue stem region (CUCAA-UUGAG) + single base left bulge (A) + 4-residue stem region (UCUUAAGA) + 9-residue asymmetrical internal loop (GAAA-AAAUA) + 2-residue stem region (GC$\mathrm{GC})+5$-residue terminal hairpin (AAAAU)

5-residue basal stem (GACCU-AGGUC) + 8-residue asymmetrical internal loop (AC-CUAUCC) + 3-residue stem region (ACC-GGU) + 3-residue asymmetrical internal loop (C-UU) + 4-residue stem region (CUCA-UGAG) + 3-residue asymmetrical internal loop (AA-A) + 4-residue stem region (UAUC-GAUA) + 9-residue asymmetrical internal loop (GAAA-AAAUA) + 2-residue stem region (GC-GC) + 5-residue terminal hairpin (AAACA)

6-residue basal stem (GACCUA-UAGGUC) + 8-residue asymmetrical internal loop (CCAUUCCU) + 3-residue stem region (ACC-GGU) + 3-residue asymmetrical internal loop (C$\mathrm{UU})+5$-residue stem region (CUCAG-CUGAG) + 3-residue asymmetrical internal loop (GA-A) + 3-residue stem region (AUC-GAU) + 9-residue asymmetrical internal loop (GAAA-AUAUA) + 3-residue stem region (AGC-GCU) + 5-residue terminal hairpin (GAACA) 4-residue basal stem (AGCA-UGCU) + 6-residue symmetrical internal loop (ACA-GAC) + 5residue stem region (UGGCG-CGUCA) + 6-residue terminal hairpin (UCAUGU)

4-residue basal stem (AGCA-UGCU) + 6-residue symmetrical internal loop (ACA-GAC) + 4residue stem region (UGGU-GCCA) + 4-residue terminal hairpin (AAUA)

4-residue basal stem (AGCA-UGCU) + 6-residue symmetrical internal loop (AAG-GAC) + 6residue stem region (UGACAU-AUGUCA) + 5-residue asymmetrical internal loop (AUA-AA) + 7-residue stem region (GCAUGAU-AUUAUGU) + 3-residue terminal hairpin (UAG) 4-residue basal stem (AGCA-UGCU) + 6-residue symmetrical internal loop (ACA-GAC) + 5residue stem region (UGGCA-UGUCA) + single base right bulge (A) + 4-residue stem region (UGUA-UAUA) + 4-residue terminal hairpin (GGUA)

4-residue basal stem (AGCA-UGCU) + 6-residue symmetrical internal loop (ACA-GAC) + 4residue stem region (UGGC-GCCA) + 4-residue terminal hairpin (UAAA)

4-residue basal stem (AGCA-UGCU) + 6-residue symmetrical internal loop (ACA-GAC) + 6residue stem region (UGACUU-AAGUCA) + 5-residue terminal hairpin (AACUG)

4-residue basal stem (AAGU-ACUU) + 5-residue asymmetrical internal loop (AA-GUA) + 11residue stem region (UUAGUAAUUGC-GUAAUUCGUAA) + 6-residue terminal hairpin (UAAUUC)

4-residue basal stem (CAGU-ACUG) + 6-residue symmetrical internal loop (GAG-AUA) + 4residue stem region (CAGU-ACUG) + 6-residue symmetrical internal loop (AAA-AAG) + 9residue stem region (CAGUAAACA-UGUGAACUG) + 6-residue symmetrical interior loop $($ GUG-AAA $)+5$-residue stem region (AUCAG-CUGAU) + 6-residue terminal hairpin (AAAAAA)

8-residue basal stem (CAAAAUUC-GAGGUUUG) + 8-residue symmetrical internal loop (GAAAAGUA) + 9-residue stem region (UUCAAAAGU-ACUUUUGGA) + 4-residue terminal hairpin (AAAC)

11-residue basal stem (CAAUUAAAAAU-AUUUUUAAUUG) + 8-residue symmetrical internal loop (GUCA-AUCA) + 17-residue stem region (AAUGCAAAAUUAAAAAU-

AUUUUUAAUUUUUAAUU) + single base left bulge (U) + 4-residue stem region (GAAUAUUC) + 3-residue terminal hairpin (UAU)

3-residue basal stem (GUA-UAC) + 6-residue symmetrical internal loop (GGU-UGA) + 11-residue stem region (AGUCAUUAGUC-GACAAAUUACU) + 8-residue symmetrical internal loop (AUUA-AAAG) + 3-residue stem region (GUC-GAC) + 8-residue symmetrical internal loop $($ AUCA-GAAG) + 3-residue stem region (GUC-GAC) + 3-residue asymmetrical internal loop $(A-A G)+5$-residue stem region (UUGUU-GACAA) + 3-residue terminal hairpin (AAA) 3-residue basal stem (GUA-UAC) + 6-residue symmetrical internal loop (GGU-UGA) + 17-residue stem region (AGUCAGAAGUCAUUUGU-ACAAAGGACAAUUGACU) + 4-residue terminal hairpin (AAAA)

8-residue basal stem (GCAGACAU-GUGUUUGC) + 19-residue asymmetrical internal loop (AGACAUUAG-AAAAAAGAAA) + 7-residue stem region (UGAGUGC-GCAGUCA) + 6residue symmetrical internal loop (CAA-GAA) + 9-residue stem region (GUCUUGGUG-

UACUUAGAC) + 3-residue right bulge (AGU) + 5-residue stem region (CUGAU-AUCAG) + 4residue terminal hairpin (UAGA)

9-residue basal stem (GCAGACACA-UGUGUUUGC) + 3-residue left bulge (GAC) + 9-residue stem region (AUUUAUUUU-GAGAUGAAU) + 5-residue terminal hairpin (UUGAU) 
Table 2. (Continued).

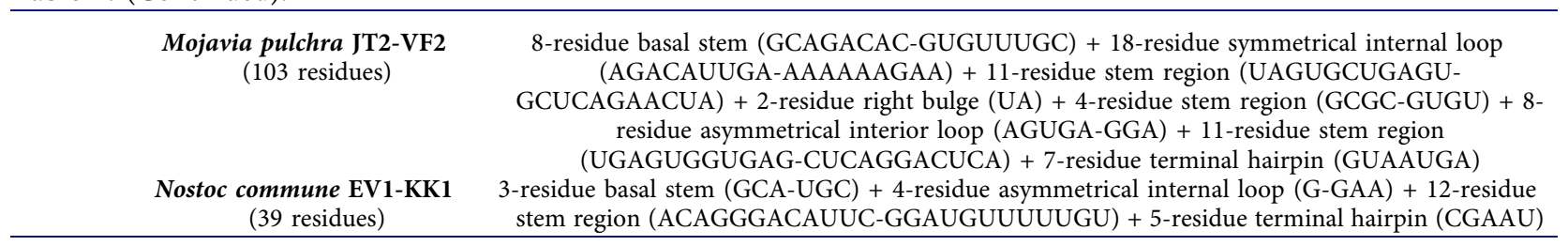

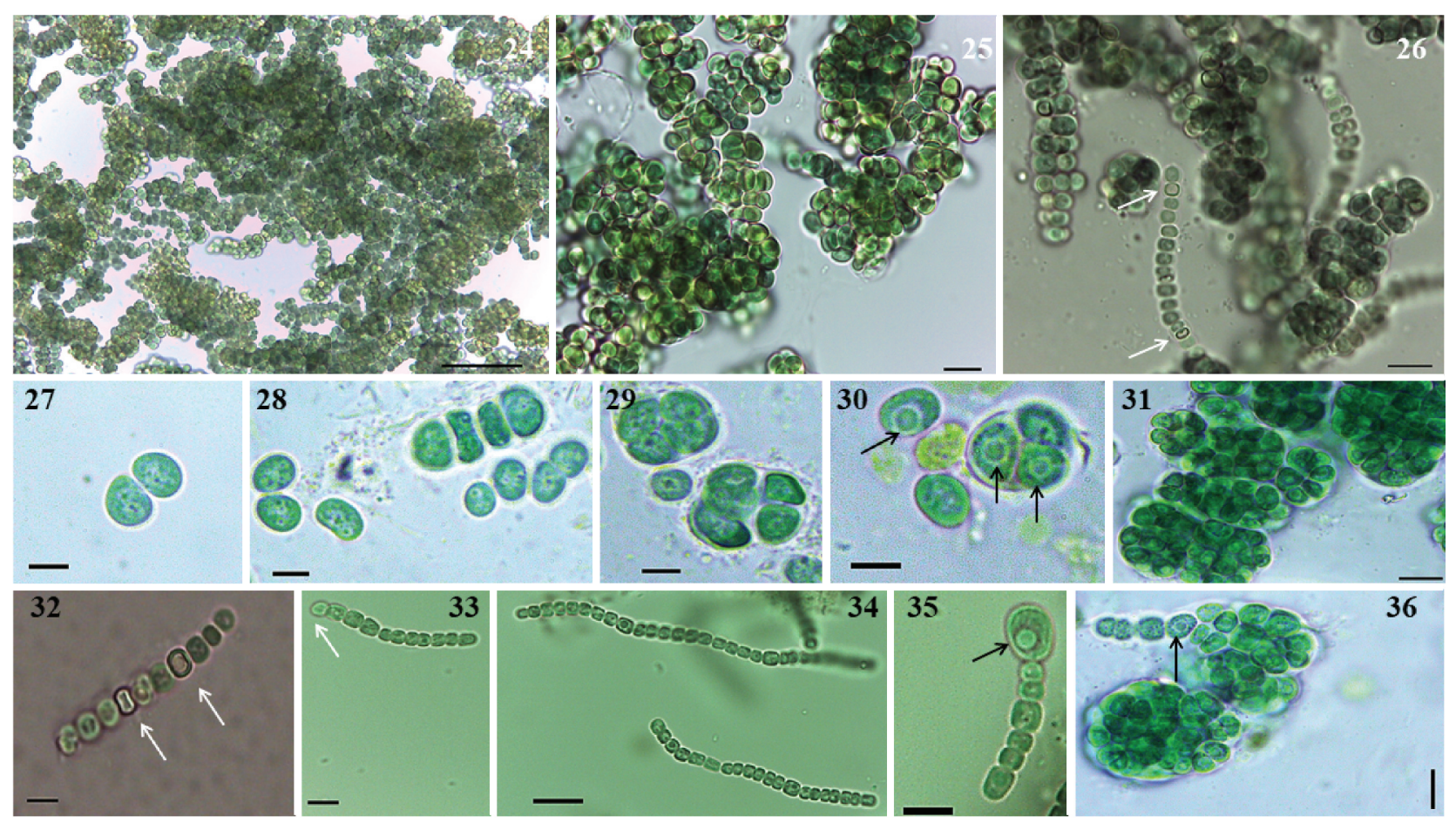

Figs 24-36. Microphotographs of Parakomarekiella sesnandensis. General characteristics of Parakomarekiella sesnandensis, showing: macroscopic colonies. Figs 24-26; equal division of akinetes. Fig. 27, forming elongated trichomes. Fig. 28; unequal division of akinetes forming spherical and encapsulated cells. Figs 29-31, 36; intercalary and terminal heterocytes. Figs 32, 33; akinete developing from a trichome. Figs 34, 35; vesicles inside the akinetes (Figs 29, 30, 34, 35, 36). Scale bar: Fig. 24, $50 \mu \mathrm{m}$; Fig. 25-26, $10 \mu \mathrm{m}$; Figs 27-30, $5 \mu \mathrm{m}$; Fig. 31, $10 \mu \mathrm{m}$; Figs 32, 33, 35, $5 \mu \mathrm{m}$; Figs 34, 36, $10 \mu \mathrm{m}$; white arrows indicate heterocysts; black arrows indicate vesicles.

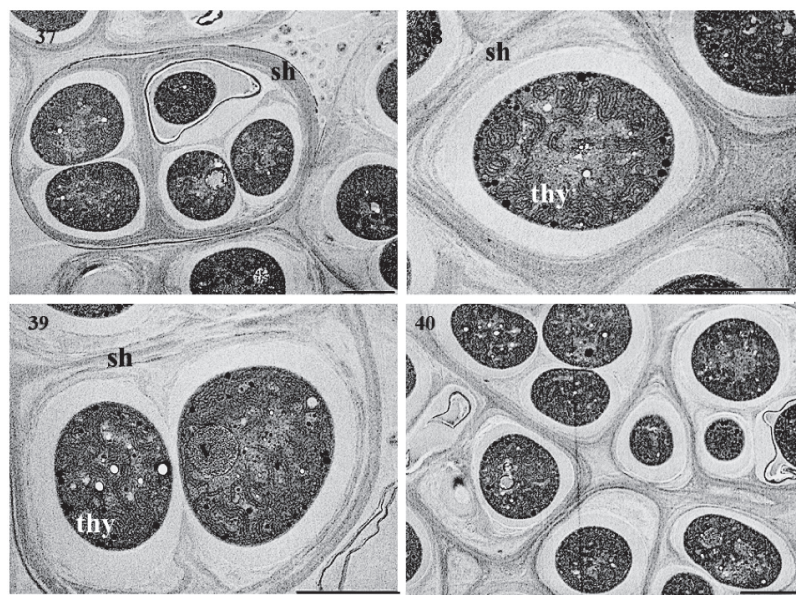

Figs 37-40. Transmission electron micrographs of cells of Parakomarekiella sesnandensis. Microphotographs showing thick and firm sheath. Figs 37-40, presence of cell inclusions/vesicles. Fig. 39, and thylakoids. Figs 38, 39. Sh, sheath; V, vesicle; Thy, thylakoids. Scale bar: $2 \mu \mathrm{m}$. reliably help in the distinction of such taxa (Komárek et al., 2014).

Regardless of being morphologically similar and showing a $16 \mathrm{~S}$ rRNA gene sequence identity of $98 \%$ with Komarekiella, the phylogenetic analyses show that our strains were distant from the Komarekiella clade, in a distinct cluster in a larger group that also encompassed the Mojavia and Nostoc sensu stricto clades. Indeed, the Parakomarekiella strains formed a genus-level clade with the 'Nostoc sp.' isolates obtained by Cuzman et al. (2010), which were not formally described in their study. According to the literature, $95 \%$ similarity for the $16 \mathrm{~S}$ rRNA marker is the threshold of distinction for certain cyanobacterial genera (Garcia-Pichel et al., 1998; Komárek, 2010; Komárek et al., 2014), and $>98.7 \%$ is used to refer to distinct prokaryotic species (Stackebrandt, 2006). However, Stackebrandt \& Goebel (1994) and Yarza et 
al. (2014) argue that prokaryote taxa with higher levels of similarity can still be described as new genera as long there is unequivocal phylogenetic, ecological or phenotypic distinctiveness, a criterion also agreed upon for Cyanobacteria (Komárek et al., 2014). Accordingly, Hentschke et al. (2017) erected the new genus Komarekiella, while observing that Komarekiella had similarity values $>95 \%$ with Halotia, Mojavia, Goleter and Aulosira and is morphologically similar to Nostoc, Desmonostoc, Halotia and Mojavia and indistinguishable from Chlorogloeopsis A.K.Mitra (Mitra \& Pandey, 1967). Similarly, although Parakomarekiella shared $>95 \%$ similarity values with the stated genera (see Table 1) and $98 \%$ with Komarekiella, our new genus represents a monophyletic lineage separate from these nostocacean genera.

The secondary structure of the 16S-23S ITS region has been used as an effective character to distinguish taxa at the species level (Boyer et al. 2001; Johansen et al. 2011; Hašler et al. 2014). This tool shows visually how the semi-conservative motifs of the ITS region (D1-D1' helix, V2, Box-B, V3) are related, providing several advantages when it comes to taxonomic criteria (Johansen et al., 2011). The D1-D1' helix of Parakomarekiella was similar to the remaining studied taxa, with the exception of Komarekiella strains, which presented 3 unpaired nucleotides on the 5' side of the helix. According to Hentschke et al. (2017), this characteristic is not common and, to date, only Pelatocladus maninholoensis is known to have four bases opposing the bulge (Miscoe et al., 2016; Hentschke et al., 2017). Although phylogenetically not related, the D1-D1' helix of Parakomarekiella presented identical structure to D. geniculatum and $N$. commune, with all three exhibiting only one nucleotide opposing the bulge. As to the Box-B helix, we found identical structures in the studied strains, with the exception of D. geniculatum and $H$. branconii, which showed different shapes and lengths. The V2 and V3 secondary structures of Parakomarekiella and remaining taxa were highly variable with no consistent pattern found. This has also been reported in other studies, where the V2 and V3 helices observed were highly variable among genera (e.g. Řeháková et al., 2007; Lukešová et al., 2009) and even between species (e.g. Shalygin et al., 2020).

From an ecological point of view, Parakomarekiella strains were isolated from two different biofilms (one was a dried green biofilm and the other was as a mixture of wet and dried green biofilm with salt efflorescence). The presence of water in one of the biofilms is believed to contribute to the solubilization of salts (mainly gypsum) in the rock surface, leading to the formation of localized efflorescence degradation (Trovão et al., 2019a). Interestingly, the 'Nostoc sp.' strains isolated by Cuzman et al. (2010) were also found associated with rock environments, the Fountain of Villa la Pietra in Italy, and Fountain from Patio de la Sultana in Spain. Some of the strains were associated with dried/sporadically wet parts of the fountains (Nostoc sp. VP2-08, Nostoc sp. 5N-02c and Nostoc sp. 2 07), while others were associated with continuously wet parts (Nostoc sp. 9E-03). This may indicate that the strains that encompassed the Parakomarekiella cluster are able to resist dried and wet environments and may possess halotolerant characteristics. Concerning the type of biofilms where they were found, Nostoc sp. VP2-08 was isolated from a black crust, Nostoc sp. 5N-02c was found associated with a grey patina and Nostoc sp. 207 was isolated from a green biofilm. Regarding the associated communities found in the biofilms, Parakomarekiella strains were associated with green algae, cyanobacteria and fungi (Soares et al., 2019a; Trovão et al., 2019a). In the study by Cuzman et al. (2010), the authors also found several cyanobacterial genera associated with the biofilms where they found 'Nostoc sp.' strains, namely Rivularia, Chroococcidiopsis, Chroococcus and Aphanocapsa. The authors have also found green microalgae from genera Apatococcus, Chlorella, Cosmarium, Dilabifilum, Monoraphidium and Scenedesmus, and fungi from genera Acremonium, Alternaria, Aspergillus, Fusarium, Phoma and Turula in the fountains where they isolated the 'Nostoc sp.' strains. Lastly, although some strains of Komarekiella were found on concrete walls, they differ from Parakomarekiella, as the climatic conditions are not the same (tropical/subtropical region $v s$ Mediterranean region, respectively).

Our future aims are to completely characterize the possible biodeterioration mechanisms that Parakomarekiella sesnandensis may encompass. With this work, we also hope to contribute to the acknowledgement of some Nostoc-like strains, encouraging the taxonomic resolution of studies still pending. Indeed, although progress has been made with the description of new genera, the polyphyly of the genus Nostoc still needs further revision.

\section{Author contributions}

FS: isolated the strains, designed the experiments, performed molecular, phylogenetic and morphological analyses, and wrote the manuscript; VR: contributed to the morphological and molecular interpretation, revised and edited the manuscript; JT: took microphotographs and contributed to phylogenetic data analysis; IT, SMC and AP supervised and coordinated the work, and revised the manuscript. All authors read and approved the final version of the manuscript.

\section{Funding}

This work was financed by FEDER- Fundo Europeu de Desenvolvimento Regional funds through the COMPETE 2020 - Operational Programme for Competitiveness and Internationalisation (POCI), and by Portuguese funds 
through FCT- Fundação para a Ciência e a Tecnologia in the framework of the project POCI-01-0145-FEDERPTDC/EPH-PAT/3345/2014. Fabiana Soares was supported by $\mathrm{POCH}$ - Programa Operacional Capital Humano (co-funding by the European Social Fund and national funding by MCTES), through a 'FCT Fundação para a Ciência e Tecnologia' $\mathrm{PhD}$ research grant (SFRH/BD/139720/2018). Vítor Ramos is grateful to FCT for financial support by national funds FCT/MCTES to CIMO (UIDB/00690/2020). João Trovão was supported by POCH - Programa Operacional Capital Humano (cofunding by the European Social Fund and national funding by MCTES), through a 'FCT - Fundação para a Ciência e Tecnologia' PhD research grant (SFRH/BD/132523/2017). Igor Tiago acknowledges an Investigator contract reference IF/01061/2014. Thanks to the Science and Technology Foundation/Ministry of Education and Science (FCT/ MEC) for funding the Organic Chemistry, Natural Products and Food Stuffs Research Unit (QOPNA) (FCT UID/QUI/00062/2019) through national funds and, where applicable, co-financed by the European Regional Development Fund (FEDER), within the Portugal2020 programme.

\section{Supplementary Information}

The following supplementary material is accessible via the Supplementary Content tab on the article's online page at https://doi.org//10.1080/09670262.2020.1817568

Supplementary data S1. 16S rRNA sequence alignment of Dataset 1 used for both Bayes and ML analyses.

Supplementary data S2. 16S rRNA sequence alignment of Dataset 2 used for both Bayes and ML analyses.

Supplementary data S3. $16 \mathrm{~S}$ rRNA 50\% majority rule Bayesian Tree regarding Dataset 1.

Supplementary data S4. 16S rRNA 50\% majority rule Bayesian Tree regarding Dataset 2.

Supplementary data S5. 16S rRNA ML IQtree regarding Dataset 1.

Supplementary data S6. 16S rRNA ML IQtree regarding Dataset 2.

Supplementary figure S1. Phylogenetic tree based on Bayesian and Maximum likelihood analyses from partial $16 \mathrm{~S}$ rRNA gene sequences (dataset 2). Since the resulting Bayesian and ML phylogenetic trees showed the same topology, a single tree with both Bayesian and ML bootstrap values is shown. Supports at the nodes (Bayesian inference/Maximum likelihood) represent posterior probabilities and bootstrap values $\geq 75$. The studied strains are shown in bold, and Gloeobacter violaceus PCC 8501 was used to root the tree. The scale bar specifies 0.05 expected changes per site.

Supplementary table S1. Data regarding the abiotic conditions in Coimbra region.

\section{Data availability}

The obtained 16S rRNA and 16S-23S rRNA sequences were submitted to GenBank (accession numbers MT044190-192).

\section{References}

Albertano, P. (2012). Cyanobacterial biofilms in monuments and caves. In Ecology of Cyanobacteria II: Their Diversity in Space and Time 1 (Whitton, B.A., editor). Springer, Dordrecht.

Altschul, S.F., Gish, W., Miller, W., Myers, E.W. \& Lipman, D.J. (1990). Basic local alignment search tool. Journal of Molecular Biology, 215: 403-410.

Bagchi, S.N., Dubey, N. \& Singh, P. (2017). Phylogenetically distant clade of Nostoc-like taxa with the description of Aliinostoc gen. nov. and Aliinostoc morphoplasticum sp. nov. International Journal of Systematic and Evolutionary Microbiology, 67: 3329-3338.

Benzerara, K., Skouri-Panet, F., Li, J., Férard, C., Gugger, M., Laurent, T. et al. (2014). Intracellular Ca-carbonate biomineralization is widespread in cyanobacteria. Proceedings of the National Academy of Sciences, 111: 10933-10938.

Bohunická, M., Pietrasiak, N., Johansen, J.R., Berrendero Gómez, N., Hauer, T., Gasina, L.A. \& Lukesová, A. (2015). Roholtiella, gen. nov. (Nostocales, Cyanobacteria) - a tapering and branching cyanobacteria of the family Nostocaceae. Phytotaxa, 197: 84-103.

Bornet, É. \& Flahault, C. (1886 '1888'). Revision des Nostocacées hétérocystées contenues dans les principaux herbiers de France (quatrième et dernier fragment). Annales des Sciences Naturelles, Botanique, 7: 177-262.

Boyer, S.L., Flechtner, V.R. \& Johansen, J.R. (2001). Is the $16 \mathrm{~S}-23 \mathrm{~S}$ rRNA internal transcribed spacer region a good tool for use in molecular systematics and population genetics? A case study in cyanobacteria. Molecular Biology and Evolution, 18: 1057-1069.

Casamatta, D.A. \& Vis, M.L. (2004). Flow rate and nutrient level effects on the morphology of Phormidium retzii (Cyanobacteria) in artificial stream mesocosms. Algological Studies, 113: 87-99.

Catarino, L., Figueiredo, R., Figueiredo, F.P., Andrade, P. \& Duarte, J. (2019). The use of dolostone in historical buildings of Coimbra (Central Portugal). Sustainability, 11: $41-58$.

Crispim, C.A. \& Gaylarde, C.C. (2005). Cyanobacteria and biodeterioration of cultural heritage: a review. Microbial Ecology, 49: 1-9.

Cunha de Oliveira, E.D., Da Cunha, A.C., Da Silva, N.B., Castelo Branco, R., Morais, J., Schneider, M.P.C., Faustino, S.M.M., Ramos, V. \& Vasconcelos, V. (2019). Morphological and molecular characterization of cyanobacterial isolates from the mouth of the Amazon River. Phytotaxa, 387: 269-288.

Cuzman, O.A., Ventura, S., Sili, C., Mascalchi, C., Turchetti, T., D'Acqui, L.P. \& Tiano, P. (2010). Biodiversity of phototrophic biofilms dwelling on monumental fountains. Microbial Ecology, 60: 81-95.

Garcia-Pichel, F., Nubel, U. \& Muyzer, G. (1998). The phylogeny of unicellular, extremely halotolerant cyanobacteria. Archives of Microbiology, 169: 469-482.

Genuário, D.B., Vaz, M.G.M.V., Hentschke, G.S., Sant'Anna, C.L. \& Fiore, M.F. (2015). Halotia gen. nov., a phylogenetically and physiologically coherent cyanobacterial genus isolated from marine coastal environments. International Journal of Systematic and Evolutionary Microbiology, 65: 663-675.

Hallmann, C. (2015). Biodiversity of terrestrial algal communities from soil and air-exposed substrates using a molecular approach. PhD thesis. (Göttingen, Germany). 
Hariot, P. (1891). Le genre Polycoccus Kützing. Journal de Botanique, 5: 29-32.

Hašler, P., Dvořák, P., Poulíčková, A. \& Casamatta, D.A. (2014). A novel genus Ammassolinea gen. nov. (Cyanobacteria) isolated from sub-tropical epipelic habitats. Fottea, 14: 241-248.

Henson, B.J., Watson, L.E. \& Barnum, S.R. (2002). Molecular differentiation of the heterocystous cyanobacteria, Nostoc and Anabaena, based on complete nifD sequences. Current Microbiology, 45: 161-164.

Hentschke, G.S., Johansen, J.R., Pietrasiak, N., Rigonato, J., Fiore, M.F. \& Sant'Anna, C.L. (2017). Komarekiella atlantica gen. et sp. nov. (Nostocaceae, Cyanobacteria): a new subaerial taxon from the Atlantic Rainforest and Kauai, Hawaii. Fottea, 17: 178-190.

Hoffmann, L. (1989). Algae of terrestrial habitats. Botanical Review, 55: 77-105.

Hrouzek, P., Ventura, S., Lukešová, A., Mugnai, M.A., Turicchia, S. \& Komárek, J. (2005). Diversity of soil Nostoc strains: phylogenetic and phenotypic variability. Algological Studies Archiv für Hydrobiologie, S117: 251-264.

Hrouzek, P., Lukešová, A., Mareš, J. \& Ventura, S. (2013). Description of the cyanobacterial genus Desmonostoc gen. nov. including D. muscorum comb. nov. as a distinct, phylogenetically coherent taxon related to the genus Nostoc. Fottea, 13: 201-213.

Iteman, I., Rippka, R., Tandeau de Marsac, N. \& Herdman, M. (2002). rDNA analyses of planktonic heterocystous cyanobacteria, including members of the genera Anabaenopsis and Cyanospira. Microbiology, 148: 481-496.

Johansen, J.R., Kovacik, L., Casamatta, D.A., Fuříková, K. \& Kaštovský, J. (2011). Utility of 16S-23S ITS sequence and secondary structure for recognition of intrageneric and intergeneric limits within cyanobacterial taxa: Leptolyngbya corticola sp. nov. (Pseudanabaenaceae, Cyanobacteria). Nova Hedwigia, 92: 283-302.

Karsten, U., Friedl, T., Schumann, R., Hoyer, K. \& Lembcke, S. (2005). Mycosporine-like amino acids and phylogenies in green algae: Prasiola and its relatives from the Trebouxiophyceae (Chlorophyta). Journal of Phycology, 41: 557-566.

Katoh, K. \& Standley, D.M. (2013). MAFFT multiple sequence alignment software version 7 : improvements in performance and usability. Molecular Biology and Evolution, 30: 772-780.

Komárek, J. (2010). Recent changes (2008) in cyanobacteria taxonomy based on a combination of molecular background with phenotype and ecological consequences (genus and species concept). Hydrobiologia, 639: 245-259.

Komárek, J. \& Anagnostidis, K. (1989). Modern approach to the classification system of Cyanophytes 4 Nostocales. Algological Studies, 56: 247-345.

Komárek, J., Kaštovský, J., Mareš, J. \& Johansen, J.R. (2014). Taxonomic classification of cyanoprokaryotes (cyanobacterial genera) 2014, using a polyphyletic approach. Preslia, 86: 295-335.

Lazaroff, N. (1966). Photoinduction and photoreversal of the Nostocacean developmental cycle. Journal of Phycology, 2: 7-17.

Lazaroff, N. \& Vishniac, W. (1961). The effect of light on the developmental cycle of Nostoc muscorum, a filamentous blue-green alga. Journal of General Microbiology, 25: 365-374.

Lowe, T.M. \& Chan, P.P. (2016). tRNAscan-SE on-line: integrating search and context for analysis of transfer RNA genes. Nucleic Acids Research, 44: W54-W57.
Lyra, C., Suomalainen, S., Gugger, M., Vezie, C., Sundman, P. et al. (2001). Molecular characterization of planktic cyanobacteria of Anabaena, Aphanizomenon, Microcystis and Planktothrix genera. International Journal of Systematic and Evolutionary Microbiology, 51: 513-526.

Lukešová, A., Johansen, J.R., Martin, M.P. \& Casamatta, D. A. (2009). Aulosira bohemensis sp. nov.: further phylogenetic uncertainty at the base of the Nostocales (Cyanobacteria). Phycologia, 48: 118-129.

Macedo, M.F., Miller, A.Z., Dionísio, A. \& Saiz-Jimenez, C. (2009). Biodiversity of cyanobacteria and green algae on monuments in the Mediterranean Basin: an overview. Microbiology, 155: 3476-3490.

Manupella, G., Moreira, J.C. \& Romão, M., (1981). Panorama dos Dolomitos e Calcários Dolomíticos Portugueses. Boletim das Minas do Instituto Geológico E Mineiro, 4: 17.

Mares, J., Strunecky, O., Bucinska, L., \& Wiedermannova, J. (2019). Evolutionary patterns of thylakoid architecture in cyanobacteria. Frontiers in Microbiology, 10: 277.

Meeks, J.C., Elhai, J., Thiel, T., Potts, M., Larimer, F. et al. (2001). An overview of the genome of Nostoc punctiforme, a multicellular, symbiotic Cyanobacterium. Photosynthesis Research 70: 85-106.

Miscoe, L.H., Johansen, J.R., Vaccarino, M.A., Pietrasiak, N. \& Sherwood, A.R. (2016). The diatom flora and cyanobacteria from caves on Kauai, Hawaii. II. Novel cyanobacteria from caves on Kauai, Hawaii. Bibliotheca Phycologica 123: 75-152.

Mitra, A.K. \& Pandey, D.C. (1967). On a new genus of the blue-green alga Chlorogloeopsis with remarks on the production of heterocytes in the alga. Phykos 5: 106-114.

Mollenhauer, D. (1970). Beiträge zur Kenntnis der Gattung Nostoc, I. Abhandlungen der Senckenbergischen Gesellschaft für Naturforschung 524: 1-80.

Moore, D., McGregor, G.B. \& Shaw, G. (2004). Morphological changes during akinete germination in Cylindrospermopsis raciborskii (Nostocales, Cyanobacteria). Journal of Phycology 40: 1098-1105.

Neilan, B.A., Jacobs, D., Del Dot, T., Blackall, L.L., Hawkins, P.R., Cox, P.T. \& Goodman, A.E. (1997). rRNA sequences and evolutionary relationships among toxic and nontoxic cyanobacteria of the genus Microcystis. International Journal of Systematic Bacteriology 47: 693-697.

Nübel, U., Garcia-Pichel, F. \& Muyzer, G. (1997). PCR primers to amplify $16 \mathrm{~S}$ rRNA genes from cyanobacteria. Applied Environmental Microbiology 63: 3327-3332.

Nylander, J.A.A. (2004). MrModeltest v2.3 Program distributed by the author. Evolutionary Biology Centre, Uppsala University.

Okonechnikov, K., Golosova, O., Fursov, M. \& UGENE team (2012). Unipro UGENE: a unified bioinformatics toolkit. Bioinformatics 28: 1166-1167.

Papaefthimiou, D., Hrouzek, P., Mugnai, M.A., Rasmussen, U., Lukešová, A., Turicchia, S. \& Ventura, S. (2008). Differential patterns of evolution and distribution of the symbiotic behaviour in nostocacean cyanobacteria. International Journal of Systematic and Evolutionary Microbiology 58: 553-564.

Perez, R., Forchhammer, K., Salerno, G. \& Maldener, I. (2016). Clear differences in metabolic and morphological adaptations of akinetes of two Nostocales living in different habitats. Microbiology 162: 214-223.

Perkerson, R.B. III, Johansen, J.R., Kovácik, L., Brand, J., Kastovsky, J. \& Casamatta, D.A. (2011). A unique pseudanabaenalean (cyanobacteria) genus Nodosilinea gen. 
nov. based on morphological and molecular data. Journal of Phycology 47: 1397-1412.

Quinta-Ferreira, M., Soares, A.F., Delgado Rodrigues, J. \& Monteiro, B. (1992). Carbonate rocks from Sé Velha Cathedral, Coimbra, Portugal. In Proceedings of the 7 th International Congress on Deterioration and Conservation of Stone, Coimbra, Portugal, 15-18 June 1992; pp. 947-956.

Rajaniemi, P., Hrouzek, P., Kastovska, K., Willame, R., Rantala, A. et al. (2005). Phylogenetic and morphological evaluation of the genera Anabaena, Aphanizomenon, Trichormus and Nostoc (Nostocales, Cyanobacteria). International Journal of Systematic and Evolutionary Microbiology 55: 11-26.

Rambaut, A. \& Drummond, A.J. (2007). Tracer v. 1.4. http://beast.bio.ed.ac.uk/Tracer.

Rambaut, A \& Drummond, A.J. (2008). FigTree: Tree figure drawing tool, v. 1.2.2. http://tree.bio. ed.ac.uk/soft ware/figtree/.

Řeháková, K., Johansen, J.R., Casamatta, D.A., Xuesong, L. \& Vincent J. (2007). Morphological and molecular characterization of selected desert soil cyanobacteria: three species new to science including Mojavia pulchra gen. et sp. nov. Phycologia, 46: 481-502.

Rippka, R.J., Deruelles, J., Waterbury, B., Herdman, M. \& Stanier, R.Y. (1979). Generic assignments, strain histories and properties of pure cultures of cyanobacteria. Journal of General Microbiology, 111: 1-61.

Ronquist, F., Teslenko, M., van der Mark, P., Ayres, D.L., Darling, A., Höhna, S., Larget, B., Liu, L., Suchard, M. A. \& Huelsenbeck, J.P. (2012). MrBayes 3.2: efficient Bayesian phylogenetic inference and model choice across a large model space. Systematic Biology, 61: 539-542.

Saiz-Jimenez, C. (1999). Biogeochemistry of weathering processes in monuments. Geomicrobiology Journal, 16: 27-37.

Saraf, A.G., Dawda, H.G. \& Singh, P. (2019). Desikacharya gen. nov., a phylogenetically distinct genus of Cyanobacteria along with the description of two new species, Desikacharya nostocoides sp. nov. and Desikacharya soli sp. nov., and reclassification of Nostoc thermotolerans to Desikacharya thermotolerans comb. nov. International Journal of Systematic and Evolutionary Microbiology, 69: 307-315.

Scheerer, S., Ortega-Morales, O. \& Gaylarde, C. (2009). Microbial deterioration of stone monuments - an updated overview. Advances in Applied Microbiology, 66: 97-139.

Seenayya, G. \& Subba Raju, N. (1972). On the ecology and systematic of the alga known as Anabaenopsis raciborskii (Wolosz). Elenk. and a critical evaluation of the forms described under the genus Anabaenopsis. In Papers submitted to the First International Symposium of Taxonomy and Biology of Blue-green Algae (Desikachary, T.V., editor), pp. 52-57.

Shalygin, S., Shalygina, R.R., Redkina, V.V., Gargas, C.B. \& Johansen, J.R. (2020). Description of Stenomitos kolaenensis and $S$. hiloensis sp. nov. (Leptolyngbyaceae, Cyanobacteria) with an emendation of the genus. Phytotaxa, 440: 108-128.

Smith, C., Heyne, S., Richter, A.S., Will, S. \& Backofen, R. (2010). Freiburg RNA tools: a web server integrating INTARNA, EXPARNA and LOCARNA. Nucleic Acids Research, 38: W373-W377.

Soares, F., Portugal, A., Trovão, J., Coelho, C., Mesquita, N., Pinheiro, A.C., Gil, F., Catarino, L., Cardoso, S.M. \& Tiago,
I. (2019a). Structural diversity of photoautotrophic populations within the UNESCO site 'Old Cathedral of Coimbra' (Portugal), using a combined approach. International Biodeterioration \& Biodegradation, 140: 9-20.

Soares, F., Tiago, I., Trovão, J., Coelho, C., Mesquita, N., Gil, F., Catarino, L., Cardoso, S.M. \& Portugal, A. (2019b). Description of Myxacorys almedinensis sp. nov. (Synechococcales, Cyanobacteria) isolated from the limestone walls of the Old Cathedral of Coimbra, Portugal (UNESCO World Heritage Site). Phytotaxa, 419: 77-90.

Stackebrandt, E. (2006). Taxonomic parameters revisited: tarnished gold standards. Microbiology Today, 33: 152-155.

Stackebrandt, E. \& Goebel, B.M. (1994). Taxonomic note: a place for DNA-DNA reassociation and 16S rRNA sequence analysis in the present species definition in bacteriology. International Journal of Systematic Bacteriology, 44: 846-849.

Sterflinger, K. \& Piñar, G. (2013). Microbial deterioration of cultural heritage and works of art - tilting at windmills? Applied Microbiology and Biotechnology, 97: 96379646.

Sukenik, A., Maldener, I., Delhaye, T., Viner-Mozzini, Y., Sela, D. \& Bormans, M. (2015). Carbon assimilation and accumulation of cyanophycin during the development of dormant cells (akinetes) in the cyanobacterium Aphanizomenon ovalisporum. Frontiers in Microbiology, 6: 1067.

Suradkar, A., Villanueva, C., Gaysina, L.A., Casamatta, D. A., Saraf, A., Dighe, G., Mergu, R. \& Singh, P. (2017). Nostoc thermotolerans sp. nov., a soil-dwelling species of Nostoc (Cyanobacteria). Journal of Systematic and Evolutionary Microbiology, 67: 1296-1305.

Trifinopoulos, J., Nguyen, L.T., von Haeseler, A. \& Minh, B.Q. (2016). W-IQ-TREE: a fast online phylogenetic tool for maximum likelihood analysis. Nucleic Acids Research, 44(W1): W232-W235.

Trovão, J., Portugal, A., Soares, F., Paiva, D.S., Mesquita, N., Coelho, C., Pinheiro, A.C., Catarino, L., Gil, F. \& Tiago, I. (2019a). Fungal diversity and distribution across distinct biodeterioration phenomena in limestone walls of the old cathedral of Coimbra, UNESCO World Heritage Site. International Biodeterioration \& Biodegradation, 142: 91-102.

Trovão, J., Tiago, I., Soares, F., Paiva, D.S., Mesquita, N., Coelho, C., Catarino, L., Gil, F. \& Portugal, A. (2019b). Description of Aeminiaceae fam. nov., Aeminium gen. nov. and Aeminium ludgeri sp. nov. (Capnodiales), isolated from a biodeteriorated artpiece in the Old Cathedral of Coimbra, Portugal. Mycokeys, 45: 57-73.

Villaneuva, C.D., Hašler, P., Dvořák, P., Poulíčková, A. \& Casamatta, D.A. (2018). Brasilonema lichenoides sp. nov. and Chroococcidiopsis lichenoides sp. nov. (Cyanobacteria): two novel cyanobacterial constituents isolated from a tripartite lichen of headstones. Journal of Phycology, 54: 224-233.

Villanueva, C.D., Garvey, A.D., Hašler, P., Dvořák, P., Poulíčková, A., Norwich, A.R. \& Casamatta, D.A. (2019). Descriptions of Brasilonema geniculatum and Calothrix dumus (Nostocales, Cyanobacteria): two new taxa isolated from cemetery tombstones. Phytotaxa, 387: $1-20$.

Will, S., Reiche, K., Hofacker, I.L., Stadler, P.F. \& Backofen, R (2007). Inferring noncoding RNA families and classes by means of genome-scale structure-based clustering. PLoS Computational Biology, 3: e65.

Will, S., Joshi, T., Hofacker, I.L., Stadler, P.F. \& Backofen, R. (2012). LocARNA-P: accurate boundary prediction 
and improved detection of structural RNAs. RNA, 18: 900-914.

Yarza, P., Yilmaz, P., Pruesse, E., Glöckner, F.O., Ludwig, W., Schleifer, K.-H., Whitman, W.B., Euzéby, J., Amann, R. \& Roselló-Morá, R. (2014). Uniting the classification of cultured and uncultured bacteria and archaea using 16S rRNA gene sequences. Nature Reviews Microbiology, 12: 635-645.

Zapomelová, E., Skaácelová, O., Pumann, P., Kopp, R. \& Janecek, E. (2012). Biogeographically interesting planktonic Nostocales (Cyanobacteria) in the Czech Republic and their polyphasic evaluation resulting in taxonomic revisions of Anabaena bergii Ostenfeld 1908 (Chrysosporum gen. nov.) and A. tenericaulis Nygaard 1949 (Dolichospermum tenericaule comb. nova). Hydrobiologia, 698: 353-365.

Zuker, M. (2003). Mfold web server for nucleic acid folding and hybridization prediction. Nucleic Acids Research, 31: 3406-3415.

Urzí, C. \& De Leo, F. (2001). Biodeterioration of Cultural Heritage in Italy: State of Art. Available online at: http:// www.arcchip.cz/w08/w08_de_leo.pdf. 